\title{
Bacterioplankton community structure: Protists control net production and the proportion of active bacteria in a coastal marine community
}

\section{Paul A. del Giorgio}

Département des sciences biologiques, Université du Québec à Montréal, Case Postale 8888, Succ. Centre Ville, Montréal, Québec H3C 3P8

\section{Josep M. Gasol and Dolors Vaqué}

Institut de Ciències del Mar, CSIC, Pg. Joan de Borbó s/n, E-08039, Barcelona, Spain

\section{Paola Mura, Susana Agustí, and Carlos M. Duarte}

Centre d'Estudis Avançats, CSIC, Camí de Sta. Bàrbara s/n, E-17300 Blanes, Girona, Spain

\begin{abstract}
A series of dialysis experiments was performed to study the relative importance of substrate limitation and grazing in controlling the proportion of active cells of coastal marine bacterioplankton. The grazer community was manipulated by filling dialysis bags with unfiltered water and water serially passed through $150-, 40-$, and $0.8-\mu \mathrm{m}$ pore-size filters. The total number of bacteria, the number of metabolically active cells, bacterial loss rates, and the abundances of heterotrophic nanoflagellates were measured immediately and at 3 and $6 \mathrm{~d}$. Gross growth rates were similar in all treatments, suggesting that ambient nutrient concentrations set an upper limit to the maximum growth rates, whereas grazing determined the net growth rates and the final number of bacteria. Bacterial loss rates, measured as the disappearance of fluorescently labeled minicells, correlated well with the initial density of heterotrophic nanoflagellates in the different treatments. The number of active cells at the end of the experiments varied widely among treatments and reached $2.0 \times 10^{6} \mathrm{ml}^{-1}$, or over $55 \%$ of the total final density in dialysis bags, with little or no grazing by nanoflagellates. The final proportion of active cells was negatively correlated to both the loss rates and the initial nanoflagellate density, and it was estimated that grazing rates on metabolically active bacteria were four or more times higher than those on inactive bacteria. Heterotrophic nanoflagellates thus seemed to control bacterial density by skimming newly growing cells rather than by cropping the standing stock of bacteria.
\end{abstract}

Bacteria are the least variable component of the plankton in terms of both total density and biomass (Cole and Caraco 1993). Large increases in phytoplankton biomass and production are accompanied by only modest increments in the total number of bacteria (del Giorgio and Gasol 1995; Ducklow and Carlson 1992). This pattern has prompted speculation that bacterial growth and abundance must be tightly regulated across aquatic systems and confined within a relatively narrow range by a combination of resource limitation and grazing (Sanders et al. 1992; Wright 1988). One issue that is seldom incorporated into models of microbial food webs is the varying proportion of metabolically active and inactive cells. In

\section{Acknowledgments}

We thank Y. Prairie, R. H. Peters (deceased), D. Bird, and two anonymous reviewers for criticism, and R. Massana, G. Carreras, and T. Cámara for lab and field assistance.

This work was supported by grants from the Spanish Interministerial Commission for Science and Technology (CICYTMAR) and from the Government of Québec through the FCAR International Cooperation Program.

This research is a contribution to project MAR-94-0746 and of the Groupe Interuniversitaire de Recherche en Limnologie (GRIL). many aquatic systems, particularly in oligotrophic areas, there seems to be a relatively large pool of metabolically inactive bacteria that has no measurable electron transport system activity (Dufour and Colon 1992) or is incapable of either substrate uptake (Riemann et al. 1984), cell growth (Kogure et al. 1987), or cell division (Riemann et al. 1984). Although the low proportion of active cells may be partly explained by methodological limitations (van Es and Meyer-Reil 1982), the different approaches converge to suggest that bacterial communities have at least two distinct pools of cells, one of dormant (or dead) bacteria and the other of metabolically active cells (Stevenson 1979; Mason et al. 1986).

Recent comparative analyses have shown that the range of variation across systems in the number of metabolically active cells is at least 10-fold greater than that of total number of cells and that the proportion of active cells tends to increase with increasing system productivity (del Giorgio and Scarborough 1995). Microbial communities thus seem to be more dynamic and less invariant across systems than is evidenced from patterns in total abundance or biomass alone. There is likely to be a constant flux of bacteria from the dormant or inactive to the active pool, but the factors that regulate the number and proportion of active and inactive cells in bacterioplankton 
are still unclear. These factors include temperature, viral infection, resource limitation, and grazing (del Giorgio and Scarborough 1995; Pace 1988). Starvation of aquatic bacteria, for example, results in a marked decrease in cell size, so that inactive or dormant bacteria tend to be smaller compared to growing cells (Morita 1982). Conversely, recent reports show that the larger bacterial size-fractions have the highest specific growth and production rates (Bird and Kalff 1993, and references therein). Because predation on bacteria by heterotrophic nanoflagellates (HNF) and other planktonic grazers is often strongly sizedependent (Jürgens and Güde 1994), metabolically active bacteria could be selectively removed from the community. The accumulation and persistence of a relatively large pool of dormant or dead bacteria is consistent with a strong size-selective removal of metabolically active cells by planktonic grazers, cropping production rather than the standing stocks of bacteria, as suggested by Sherr et al. (1992). Although there is circumstantial evidence to support this hypothesis (Sherr and Sherr 1994), it has never been explicitly tested in natural bacterioplankton communities.

Here we test the hypothesis that HNF graze selectively on metabolically active bacteria and thereby control not only total bacterial density but also the fraction of the bacterioplankton community that is inactive or dormant. We tested this hypothesis in a NW Mediterranean coastal environment in experiments where in the grazer community was manipulated and samples were incubated in dialysis bags, which allow relatively free exchange of most inorganic and organic solutes. Thus, bacterial populations were growing at ambient nutrient concentration but under different grazing pressures. In our experiments, we have identified metabolically active cells as those capable of reducing the tetrazolium salt CTC (Rodriguez et al. 1992; Schaule et al. 1993) to its fluorescent formazan, which accumulates intracellularly and can be detected with epifluorescence microscopy.

\section{Materials and methods}

Sampling area and experimental design-The experiments described here were performed in the Bay of Blanes on the Mediterranean coast of northern Spain $\left(41^{\circ} 39.90^{\prime} \mathrm{N}\right.$, $2^{\circ} 48.03^{\prime} \mathrm{E}$ ) from 12 to 18 April 1994. Background data of the site and the prevailing biological, physical, and chemical conditions of the sea at the time of the experiments are summarized elsewhere (Mura et al. 1996). The experiments involved the size fractionation of plankton samples using screens of different pore sizes and the incubation of these size-screened water samples in dialysis bags suspended in situ. Total bacterial density, the number of active cells, bacterial loss rates, and the density of HNF were followed along the experiment in the different treatment bags. Two almost identical series of experiments were performed with a 3-d difference in the same location.

Experiment 1-Dialysis bags (Spectra/Por 1, weight cutoff of $6,000-8,000$ daltons, $80-\mathrm{mm}$ flat width) were cut to a length of $20-25 \mathrm{~cm}$ to hold $\sim 400-500 \mathrm{ml}$. The bags were thoroughly washed in hot tapwater, rinsed overnight, and then soaked for at least $3 \mathrm{~h}$ in distilled water before the experiments began. The washed bags were then clamped on one end. Subsurface water samples were collected from a motorboat and serially filtered on deck through 150 - and $40-\mu \mathrm{m}$ pore-size screens by gravity and through $0.8-\mu \mathrm{m}$ Nuclepore membranes by gently pressing the water through a syringe filter set. Three replicate dialysis bags were filled for each of the four treatments: A (unfiltered water), B (water filtered through 150 $\mu \mathrm{m}$ ), C (water filtered through 150 and $40 \mu \mathrm{m}$ ), and D (water filtered through 150, 40, and $0.8 \mu \mathrm{m}$ ). Experiment 1 was designed to follow the changes within the bags and in the surrounding waters at 0,3 , and $6 \mathrm{~d}$ so two sets of triplicate bags were prepared for each of the four treatments. Samples of unfiltered water and water from each size fraction were collected and kept in cooled containers for subsequent analysis of ambient conditions.

Before the open ends of the filled dialysis bags were clamped, minicells were dispensed into each bag (see below). The contents of the bags were thoroughly mixed, and $25-\mathrm{ml}$ samples were collected from cach bag and preserved with an equal volume of ice-cold $4 \%$ glutaraldehyde to determine the initial concentrations of minicells, total and active bacteria, and HNF in each bag. The bags were then tightly clamped and tied inside a plastic frame cage to avoid physical damage. The cage was suspended $\sim 2 \mathrm{~m}$ below the surface and tied to a buoy moored at a depth of $\sim 10 \mathrm{~m}$.

At days 3 and 6, the dialysis bags were retrieved and placed in a water-filled cooler for transport to the laboratory. Some of the triplicate samples were lost either during the incubation or during retrieval. Samples of unfiltered and size-fractioned seawater were also taken for analysis of ambient conditions at days 3 and 6 . In the laboratory, the contents of each bag were placed in a plastic bottle, and subsamples were taken and processed for the enumeration of total bacterial abundance and the number of active cells, the number of minicells, and the density of heterotrophic nanoflagellates, as outlined below.

Experiment 2-This experiment was carried out $3 \mathrm{~d}$ after experiment 1 and was similar to it, except that there were only three treatments (water filtered through 150 , 40 , and $0.8 \mu \mathrm{m}$; no unfiltered water), and only one set of triplicate bagss was filled for each treatment and retrieved at day 3.

Determination of active and total number of bacteriaNo more than $1 \mathrm{~h}$ after collection, ambient water samples and the water incubated in the dialysis bags were processed to quantify the number of respiring bacteria, following the CTC method proposed by Rodriguez et al. (1992). The water samples were incubated at in situ temperature $\left(14^{\circ} \pm 1^{\circ} \mathrm{C}\right)$ in the presence of the tetrazolium salt CTC (5-cyano-2, 3-ditolyl tetrazolium chloride) at a final concentration of $5 \mathrm{mM}$ for $8-10 \mathrm{~h}$. The incubation times of samples with CTC were determined in previous studies 
(del Giorgio and Scarborough 1995). CTC enters all cells but is reduced to its red fluorescent formazan only in cells that possess an active electron transport system (Rodriguez et al. 1992; Schaule et al. 1993). Incubation was stopped with formaldehide (3\%), and DAPI $\left(1 \mu \mathrm{g} \mathrm{ml}^{-1}\right)$ was added to the samples to double-stain the entire bacterial population. Finally, the samples were passed through a $0.2-\mu \mathrm{m}$ black Nuclepore membrane filter and the membranes mounted under low fluorescence immersion oil. Metabolically active cells with red fluorescent deposits of CTC-formazan were enumerated with an epifluorescence microscope equipped with a rhodamine filter block (excitation, $510-560 \mathrm{~nm}$; barrier filter, $580 \mathrm{~nm}$ ). Total bacterial abundance was determined in the same preparation by shifting to the UV excitation filter and enumerating the DAPI-stained cells. A minimum of 200 CTC-positive cells and 500 DAPI-stained cells were counted in each filter using a Zeiss Axioplan microscope at 1,250 $\times$ magnification.

Heterotrophic nanoflagellates-To determine the density of HNF in all the treatments and in the ambient scawater, we stained $15-20 \mathrm{ml}$ of glutaraldehyde-fixed samples with DAPI $\left(5 \mu \mathrm{g} \mathrm{ml}^{-1}\right)$, passed it through black $0.8-\mu \mathrm{m}$ Nuclepore filters, and counted the protozaons with epifluorescence using a Zeiss Axioplan microscope under $400 \times$ magnification.

Bacterial loss and growth rates - Bacterial loss rates [ $g_{(t)}$, $\mathrm{d}^{-1}$ ] were obtained by measuring the rate of disappearance of minicells over $3 \mathrm{~d}$ in the water enclosed in the dialysis bags (Vaqué et al. 1994a). The minicell stock (minicell-producing strain X-1488, Genetic Stock Center, Yale Univ.) was prepared according to Pace et al. (1990); cells were heat-killed, stained with DTFA, and added to the experimental bags at a concentration of $\sim 2-4 \times 10^{5}$ $\mathrm{ml}^{-1}(\sim 20 \%$ of the natural bacterial density). The minicells obtained were spherical and $\sim 0.5 \mu \mathrm{m}$ in diameter (mean vol., $0.065 \mu \mathrm{m}^{3}$ ), similar to the mean size of the natural bacterioplankton (mean vol., $0.06 \mu \mathrm{m}^{3}$, see discussion). Sample aliquots of 2-4 $\mathrm{ml}$ were concentrated on Nuclepore $0.22-\mu \mathrm{m}$ filters, and the minicells were counted under epifluorescence with an FITC combination filter set. The time-course development of the number of minicells in the initial and final samples of the experiment was fitted to an exponential model (Salat and Marrasé 1994).

Bacterial net growth rates $\left(r, \mathrm{~d}^{-1}\right)$ inside the bags and in the surrounding water were calculated from the difference in abundances from day 0 to day 3 , assuming exponential growth (Ducklow and Hill 1985):

$$
N_{t}=N_{0} \exp (r t) \text {. }
$$

This same model was applied whether growth rates were calculated from changes in the total cell density $\left[r_{(t)}\right]$ or from changes in the number of active bacteria $\left[r_{(\mathrm{a})}\right]$. Bacterial gross growth rates $\left(\mu, \mathrm{d}^{-1}\right)$ were calculated as

$$
\mu=r+g \text {. }
$$

Table 1. List of abbreviations, the variables and units to

\begin{tabular}{|c|c|c|}
\hline Abbrev & Variable and units & Method \\
\hline TOT & $\begin{array}{l}\text { Total bacterial number, } \\
10^{6} \mathrm{ml}^{-1}\end{array}$ & $\begin{array}{l}\text { DAPI staining/epifluo- } \\
\text { rescence }\end{array}$ \\
\hline $\mathrm{ACT}$ & $\begin{array}{l}\text { No. of metabolically ac- } \\
\text { tive bacteria, } 10^{6} \\
\mathrm{ml}^{-1}\end{array}$ & $\begin{array}{l}\text { Intracellular reduction } \\
\text { of CTC/epifluores- } \\
\text { cence }\end{array}$ \\
\hline INACT & $\begin{array}{l}\text { No. of metabolically in- } \\
\text { active bacteria, } 10^{6} \\
\mathrm{ml}^{-1}\end{array}$ & TOT - ACT \\
\hline HNF & $\begin{array}{l}\text { No. of heterotrophic } \\
\text { nanoflagellates, } \mathrm{ml}^{-1}\end{array}$ & $\begin{array}{l}\text { DAPI staining/epifluo- } \\
\text { rescence }\end{array}$ \\
\hline$r_{(t)}$ & $\begin{array}{l}\text { Net growth rate of all } \\
\text { cells, } d^{-1}\end{array}$ & $\begin{array}{l}\text { Change in total cells } \\
\text { counts with time }\end{array}$ \\
\hline$r_{\text {(a) }}$ & $\begin{array}{l}\text { Net growth rate of ac- } \\
\text { tive bacteria, } d^{-1}\end{array}$ & $\begin{array}{c}\text { Change in No. of active } \\
\text { bacteria with time }\end{array}$ \\
\hline$r_{(\mathrm{i})}$ & $\begin{array}{l}\text { Net growth rate of inac- } \\
\text { tive bacteria, } \mathrm{d}^{-1}\end{array}$ & $\begin{array}{l}\text { Change in No. of inac- } \\
\text { tive bacteria with } \\
\text { time }\end{array}$ \\
\hline$g_{(\mathrm{t})}$ & $\begin{array}{l}\text { Loss rates of all cells, } \\
\mathrm{d}^{-1}\end{array}$ & $\begin{array}{l}\text { Disappearance of mini- } \\
\text { cells }\end{array}$ \\
\hline$g_{\text {(a) }}$ & $\begin{array}{l}\text { Loss rates of active bac- } \\
\text { teria, } \mathrm{d}^{-1}\end{array}$ & $\mu_{(\mathrm{a})}-r_{(\mathrm{a})}$ \\
\hline$g_{(\mathrm{i})}$ & $\begin{array}{l}\text { Loss of inactive bacte- } \\
\text { ria, } \mathrm{d}^{-1}\end{array}$ & Fitted (see text) \\
\hline$\mu_{(\mathrm{t})}$ & $\begin{array}{l}\text { Gross growth rate of all } \\
\text { cells, } d^{-1}\end{array}$ & $r_{(\mathrm{t})}+g_{(\mathrm{t})}$ \\
\hline$\mu_{(\mathrm{a})}$ & $\begin{array}{l}\text { Gross growth rate of } \\
\text { active cells, } d^{-1}\end{array}$ & $\begin{array}{l}r_{(\mathrm{a})} \text { in samples were } g_{\text {(t) }} \\
\quad=0\end{array}$ \\
\hline$\mu_{(i)}$ & $\begin{array}{l}\text { Gross growth rate of in- } \\
\text { active cells, } \mathrm{d}^{-1}\end{array}$ & $\begin{array}{l}r_{(\mathrm{i})} \text { in samples were } g_{(\mathrm{t})} \\
\quad=0\end{array}$ \\
\hline
\end{tabular}
which they correspond, and summary of methods.

Table 1 summarizes the measurements taken during the experiments, the parameters that were calculated from these data, and the abbreviations used in the text.

\section{Results}

At the time of the experiment, water temperature off the Mediterranean coast of Blanes was $14-15^{\circ} \mathrm{C}$, the spring phytoplankton bloom had subsided, and chlorophyll concentrations were $\sim 0.3-0.4 \mu \mathrm{g}$ liter ${ }^{-1}$, close to the seasonal average recorded for the Bay of Blanes (Mura et al. 1996). Nitrate concentrations were low $(0.2 \mu \mathrm{M})$, and phosphate concentrations were below detection limits. The phytoplankton community was dominated by eucaryotic and procaryotic picoplankton and Chaetoceros sp. Despite low nutrient concentrations, phytoplankton achieved rates of production of $>13 \mu \mathrm{g} \mathrm{C}$ liter $^{-1} \mathrm{~d}^{-1}$ (Mura et al. 1996).

HNF abundance and bacterial loss rates-Average bacterial loss rates within treatments, estimated from the disappearance of minicells, ranged from a high of 0.47 $\mathrm{d}^{-1}$ to 0 (Fig. 1A). Bacterial loss rates were strongly correlated to the initial concentration of HNF in the individual bags (Fig. 2A), suggesting that protistan grazing was the main cause for bacterial loss. Ambient HNF and ciliate densities avcraged $820 \mathrm{ml}^{-1}$ and $2 \times 10^{3}$ liter $^{-1}$, 

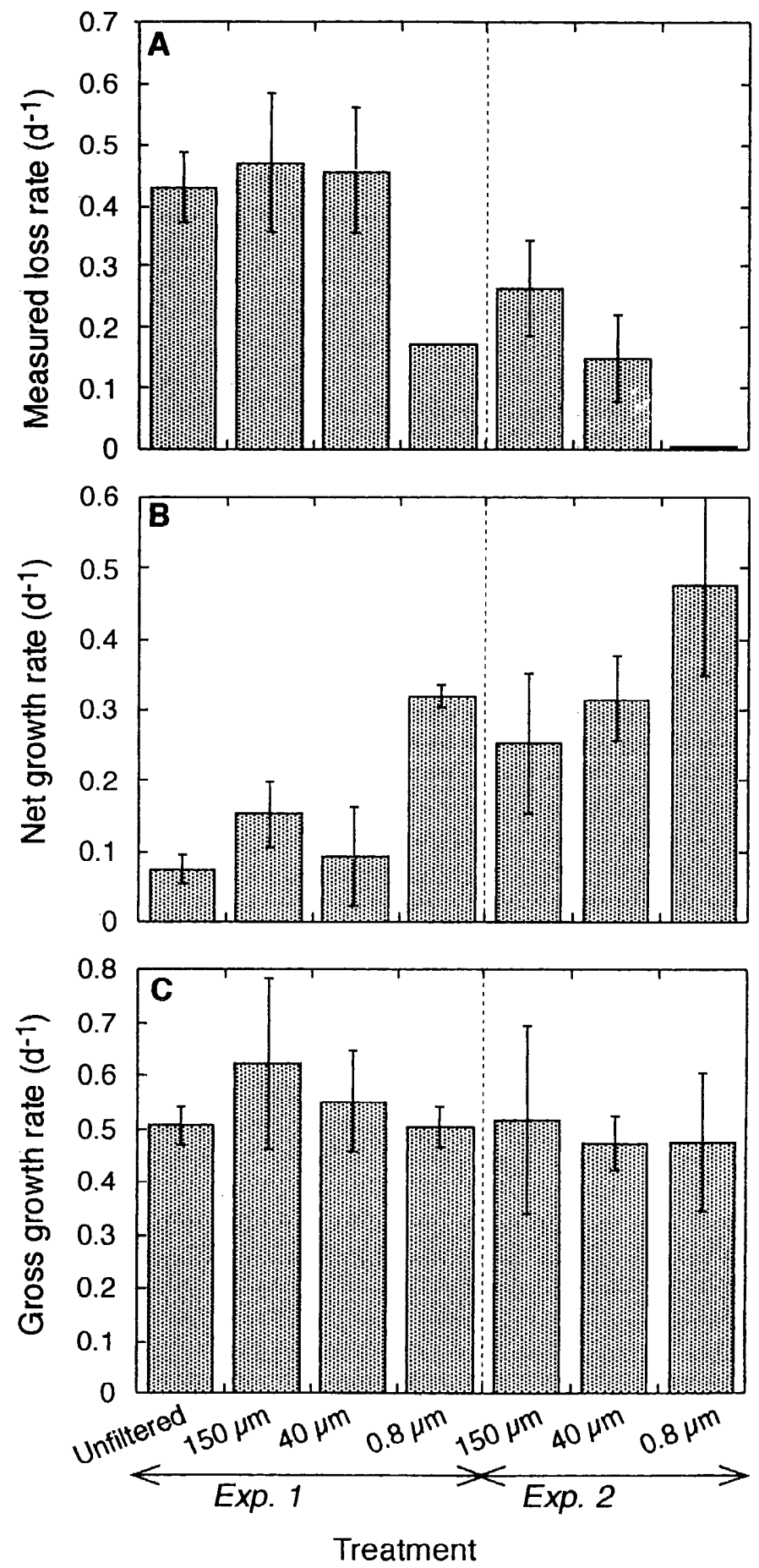

Fig. 1. Average bacterial loss rates $\left[g_{(t)}\right]$, net growth rates $\left[r_{(t)}\right]$, and gross growth rates $\left[\mu_{(t)}\right]$ for the different filtration treatments, calculated on the basis of the total bacterial density. Error bars represent $1 \mathrm{SD}$.

respectively, and remained constant during the 3-d delay period between the start of experiments 1 and 2 . Serial filtration yielded variable abundances of grazers among the bags (Table 2). Filtration through $0.8 \mu \mathrm{m}$, for example, did not completely exclude HNF from any of the samples.
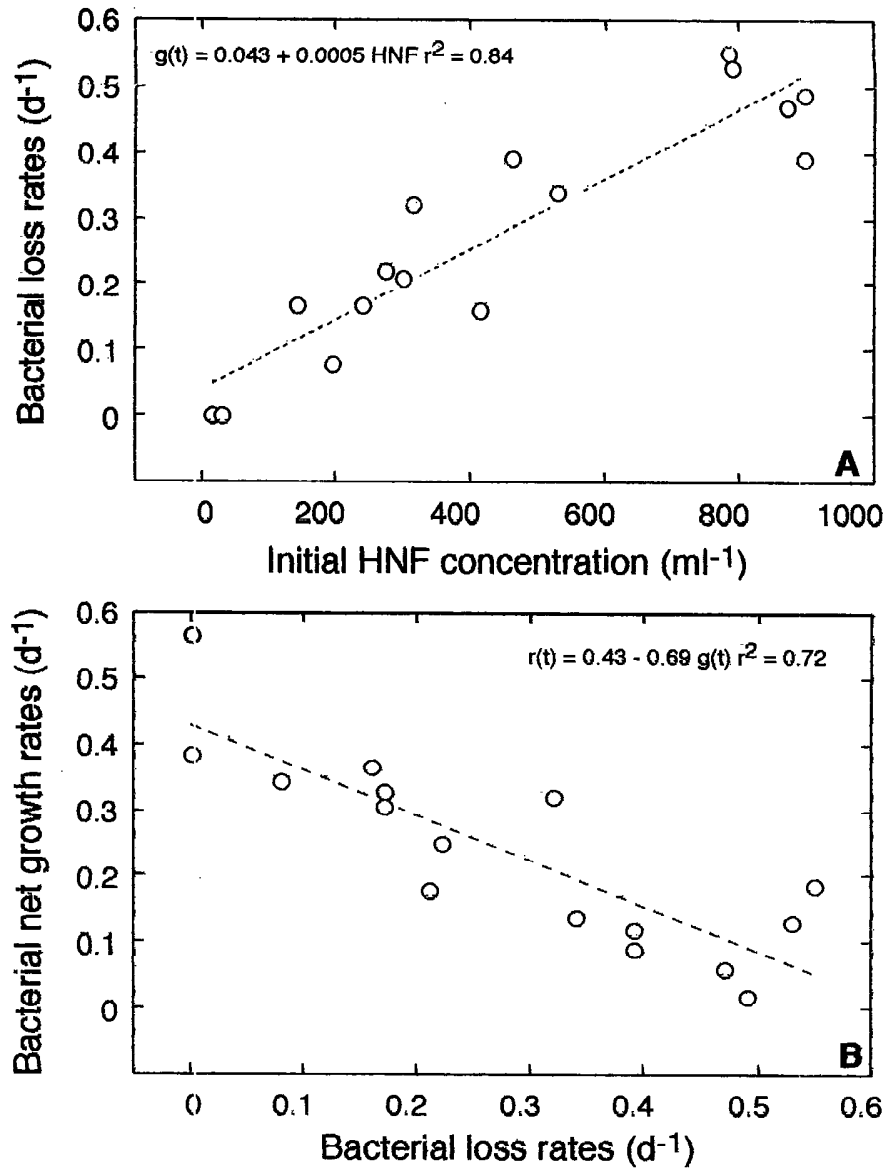

Fig. 2. A. The relationship between bacterial loss rates $\left[g_{(t)}\right]$ and the initicl concentration of HNF in the dialysis bags. $B$. The relationship between total bacterial net growth rate $\left[r_{(t)}\right]$ and bacterial loss rates $\left[g_{(\mathrm{t})}\right]$ in the same bags. Data from the individual dialysis bags are shown.

In experiment 1 , abundances between 100 and 250 protists $\mathrm{ml}^{-1}$ were encountered in the $0.8-\mu \mathrm{m}$ filtrates, resulting in low but measurable bacterial loss rates in these bags $\left[g_{(\mathrm{t})}=0.17 \mathrm{~d}^{-1}\right]$. The same procedure seemed to be more effective in experiment 2 , because the number of HNF in the $\left(0.8-\mu \mathrm{m}\right.$-filtered samples was lower $\left(<30 \mathrm{ml}^{-1}\right)$ and there were no measurable losses of minicells in these samples $\left[g_{(\mathrm{t})} \cong 0\right]$, suggesting that those HNF which passed the membrane may have been injured or killed.

Bacterial inet and gross growth rates-Ambient bacterial abundances were $0.87 \times 10^{6} \mathrm{ml}^{-1}$, whereas the number of active cells was $0.062 \times 10^{6} \mathrm{ml}^{-1}$, or $7.1 \%$ of the total density (Table 2). Bacterial net growth rates in the dialysis bags, calculated from the changes in total bacterial abundance from $t=0$ to $t=3 \mathrm{~d}$, varied from 0.075 to $0.47 \mathrm{~d}^{-1}$ (Fig. 1B), and bacterial gross growth rates, calculated as the sum of bacterial net growth rates and loss rates, were remarkably constant among treatments and experiments (Fig. 1C), averaging $0.52 \mathrm{~d}^{-1}$ in all the samples (Table 2). Net bacterial growth rates varied inversely with loss rates (Fig. 2B). In unscreened samples (treatment $A_{\mathrm{l}}$ ), net bacterial growth rates were extremely 
Table 2. Results of dialysis experiments 1 and 2. Letters are the treatments: A-unfiltered water; B-water filtered through 150 $\mu \mathrm{m}$; C-water filtered through $40 \mu \mathrm{m}$; D-water filtered through $0.8 \mu \mathrm{m}$. Numbers following letters refer to individual replicate bags in each treatment. Abbreviations of variables and units are given in Table 1 , and subindices refer to day 0,3 , and $6 . P$ is the percent active bacteria.

\begin{tabular}{|c|c|c|c|c|c|c|c|c|c|c|c|c|}
\hline & $\mathrm{TOT}_{0}$ & $\mathrm{ACT}_{0}$ & $P_{0}$ & $\mathrm{HNF}_{0}$ & $\mathrm{TOT}_{3}$ & $\mathrm{ACT}_{3}$ & $P_{3}$ & $g_{(t)}$ & $\mathrm{HNF}_{3}$ & TOT $_{6}$ & $\mathrm{ACT}_{6}$ & $P_{6}$ \\
\hline \multicolumn{13}{|c|}{ Experiment 1} \\
\hline A1 & 0.87 & 0.062 & 7.1 & 465 & 1.14 & 0.28 & 24.6 & 0.39 & 1,594 & 1.93 & 0.29 & 15.0 \\
\hline A2 & 0.87 & 0.062 & 7.1 & 868 & 1.04 & 0.19 & 18.3 & 0.47 & 4,633 & 1.64 & 0.24 & 14.6 \\
\hline B1 & 0.82 & 0.056 & 6.8 & 897 & 1.17 & 0.19 & 16.2 & 0.39 & 2,279 & 2.16 & 0.40 & 18.5 \\
\hline B2 & 0.82 & 0.056 & 6.8 & 783 & 1.43 & 0.33 & 23.1 & 0.55 & 1,247 & 1.51 & 0.23 & 15.2 \\
\hline $\mathrm{C} 1$ & 0.87 & 0.046 & 5.6 & 897 & 0.92 & 0.13 & 12.1 & 0.49 & 3,070 & 1.54 & 0.23 & 14.9 \\
\hline $\mathrm{C} 2$ & 0.87 & 0.046 & 5.6 & 530 & 1.32 & 0.12 & 9.1 & 0.34 & 3,110 & 2.41 & 0.41 & 17.0 \\
\hline $\mathrm{C} 3$ & 0.87 & 0.046 & 5.6 & 789 & 1.29 & 0.14 & 10.8 & 0.53 & 2,131 & - & - & - \\
\hline D1 & 0.74 & 0.044 & 5.9 & 241 & 1.99 & 0.83 & 41.7 & 0.17 & 365 & 3.03 & 1.30 & 42.9 \\
\hline D2 & 0.74 & 0.044 & 5.9 & 144 & 1.86 & 0.81 & 43.6 & 0.18 & 319 & 3.16 & 1.16 & 36.7 \\
\hline \multicolumn{13}{|c|}{ Experiment 2} \\
\hline B1 & 0.86 & 0.055 & 6.4 & 299 & 1.48 & 0.47 & 31.8 & 0.21 & 732 & - & - & - \\
\hline B2 & 0.86 & 0.055 & 6.4 & 315 & 2.26 & 0.43 & 19.0 & 0.32 & 1,425 & - & - & - \\
\hline $\mathrm{C} 1$ & 0.79 & 0.048 & 6.1 & 196 & 2.40 & 1.01 & 41.7 & 0.08 & 1,258 & - & - & - \\
\hline $\mathrm{C} 2$ & 0.79 & 0.048 & 6.1 & 414 & 2.37 & 0.41 & 17.3 & 0.16 & 1,096 & - & - & - \\
\hline $\mathrm{C} 3$ & 0.79 & 0.048 & 6.1 & 272 & 1.68 & 0.46 & 27.4 & 0.22 & 887 & - & - & - \\
\hline D1 & 0.68 & 0.044 & 6.5 & 15 & 2.15 & 1.31 & 60.9 & 0 & 180 & - & - & - \\
\hline D2 & 0.68 & 0.044 & 6.5 & 29 & 3.70 & 2.03 & 54.9 & 0 & 109 & - & - & - \\
\hline
\end{tabular}

low, whereas net growth of the ambient bacterial populations during the experiments was negligible $\left(<0.02 \mathrm{~d}^{-1}\right)$ during the same $3-d$ period.

Changes in the number and proportion of active cellsThe number of metabolically active cells changed dramatically during the course of the experiments and was more variable among treatments than the total number of bacteria (Table 2). Initial numbers of active cells ranged from 0.062 to $0.044 \times 10^{6} \mathrm{ml}^{-1}$ among treatments, representing $5.6-7.1 \%$ of the total bacterial number. At $t=$ $3 \mathrm{~d}$ the numbers ranged from 0.12 to $2.03 \times 10^{6} \mathrm{ml}^{-1}$, which represents a 46-fold variation. In contrast, total bacterial numbers varied $<6$-fold during the course of the experiments, from initial densities ranging from 0.68 to $0.87 \times 10^{6} \mathrm{ml}^{-1}$ to final densities ranging from 0.92 to $3.7 \times 10^{6} \mathrm{ml}^{-1}$ (Table 2). The proportion of active cells was an inverse function of bacterial loss rates (Fig. 3). In bags in which the initial number of HNF was very low and loss rates were small or negligible (treatment D), the proportion of active cells exceeded $55 \%$ at the end of the experiments and was 7-8 times higher than the proportion of active cells in the ambient water.

Results at day 6-All the calculations so far have been based on the results of the 3-d incubations, and it is possible that longer term incubations could result in different patterns of growth and grazing. Experiment 1 was continued to day 6 , and the data appear in Table 2 . Bacteria continued to increase with net growth rates similar to those described for the first $3 \mathrm{~d}$ of the experiment, and the differences among treatments $\mathrm{A}, \mathrm{B}$, and $\mathrm{C}$ tended to disappear, probably as a result of the stabilization of the number of HNF in these bags. More importantly, how- ever, the proportion of active cells shows essentially the same pattern at day 6 than described above for day 3 . The bags with low initial density of flagellates (treatment D) still had significantly higher proportions of active cells, exceeding $40 \%$ after $6 \mathrm{~d}$ of incubation (Fig. 4).

\section{Discussion}

Our results indicate that bacterial gross growth rates, calculated as the sum of measured net growth rates and loss rates, were very similar among treatments, suggesting that ambient nutrient concentrations and temperature set

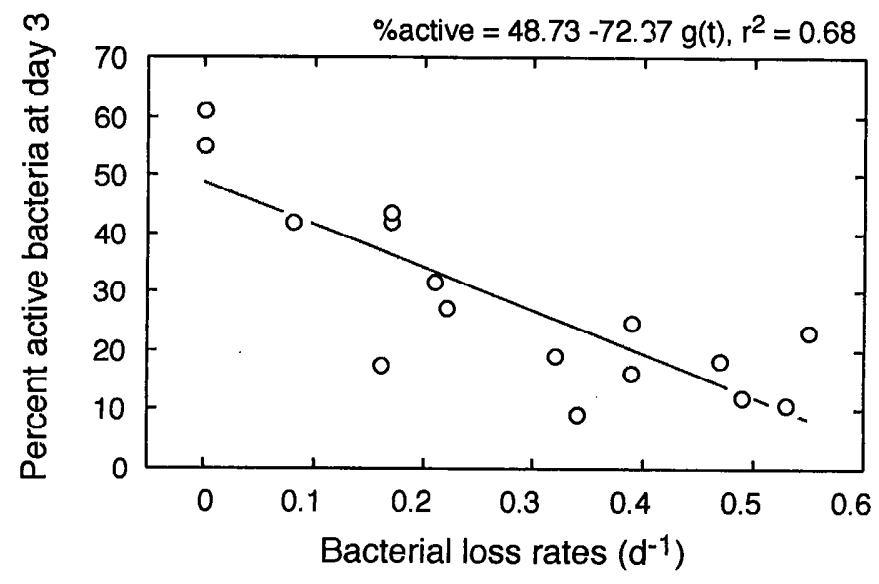

Fig. 3. The relationship between the percent active bacteria in the dialysis bags after $3 \mathrm{~d}$ of incubation and the bacterial loss rates measured during the same period. Data from individual dialysis bags are shown. 


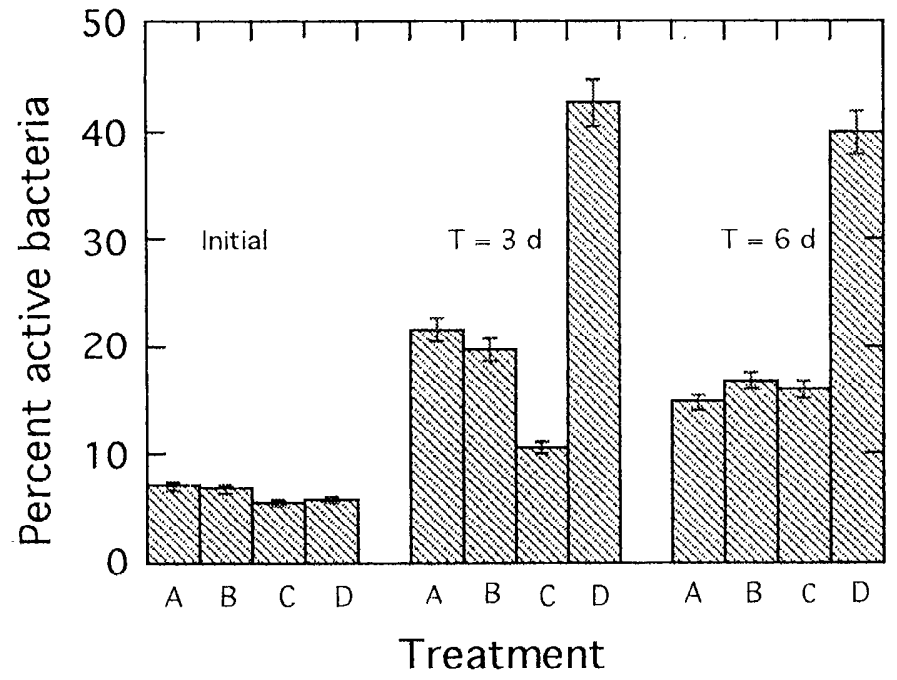

Fig. 4. The average percentage of active bacteria ( \pm 1 SD) in the different treatments of experiment 1 at time 0 and after 3 and $6 \mathrm{~d}$ of incubation.

an upper limit to the maximum growth rates, whereas grazing determined the net growth rates and the final number of bacteria. Net growth of the ambient bacterial populations during the experiments was negligible $(<0.02$ $\mathrm{d}^{-1}$ ), so growth in the open water was probably balanced by grazing losses. In contrast, growth inside the dialysis bags was always higher than in the open water and was negatively correlated to both bacterial loss rates and the initial density of HNF in the bags. HNF, in turn, had no measurable net growth in the open water during the experiment, whereas densities inside the bags increased by as much as 6-fold, with net growth rates exceeding 0.4 $\mathrm{d}^{-1}$ (Table 2), suggesting that the treatments somehow uncoupled a tight link between flagellate protists and their predators. Results reported elsewhere indicate that phytoplankton production and biomass were also tightly controlled by metazoan grazers (Mura et al. 1996). On the whole, therefore, the plankton community of the Bay of Blanes seemed strongly regulated by trophic interactions, despite the low ambient nutrient and organic carbon concentrations at the time of the experiments.

Besides the evidence for strong grazer control of coastal bacterial populations, there are two major findings in our study. First, the evidence that protistan grazing determined the proportion of metabolically active bacteria suggests strong selective grazing on metabolically active cells. Second, during the course of the incubations there was a significant proportion of cells that entered the inactive pool, despite exponential growth evidenced by the community. The rate of cell inactivation seemed to be higher than the grazing rate on inactive cells, because in all treatments there was a net increase in the number of dormant cells. These results suggest more complex internal dynamics within microbial assemblages than is normally assumed, and it becomes important to explore some of these interactions. Although we did not directly measure grazing on active and inactive cells or the rate of cell inactivation, these rates may be roughly approximated by combining the results of our experiments with a set of plausible assumptions, as we do in the following section.

Growth rates of active cells - The initial pool of CTC(-) cells was assumed to remain inactive during the course of the incubation, so the increase in the number of bacteria in the bags was due to the initial pool of CTC(+) cells. Because loss rates were close to 0 in the two replicate bags of the $0.8-\mu \mathrm{m}$ filtrate in experiment 2 (D2, Table 2), it can be assumed that bacterial net growth rates $(r=0.47$ $\mathrm{d}^{-1}$ average of the replicate bags) approached gross or maximum growth rates $\left[\mu_{(t)}\right]$ in these bags. The average initial bacterial density (TOT) in the D2 bags was $0.68 \times 10^{6} \mathrm{ml}^{-1}$, whereas the initial number of active cells (ACT) was $0.044 \times 10^{6} \mathrm{ml}^{-1}$, or $6.5 \%$ of the total bacterial population (Table 2). By day 3 , on average, TOT had increased to $2.92 \times 10^{6} \mathrm{ml}^{-1}$, ACT to $1.67 \times 10^{6} \mathrm{ml}^{-1}$, and INACT to $1.25 \times 10^{6} \mathrm{ml}^{-1}$ in the D2 bags. The number of new cells produced at $t=3 \mathrm{~d}$ was $2.28 \times 10^{6} \mathrm{ml}^{-1}$ because in the absence of grazing, the initial pool of inactive cells is assumed to move unchanged to $t=3$. Because all the new cells are assumed to originate from the initial pool of active cells, the average gross growth rate of active bacteria in the D2 bags was $1.32\left(\mathrm{~d}^{-1}\right)$.

The number of new cells in D2 at $t=3 \mathrm{~d}\left(2.28 \times 10^{6}\right.$ $\mathrm{ml}^{-1}$ ) was higher than the number of active cells at $t=$ $3 \mathrm{~d}\left(1.67 \times 10^{6} \mathrm{ml}^{-1}\right)$, suggesting that a certain fraction of the new cells became inactivated or died during the course of the experiment. The number of new cells that became dormant or nonresponsive to CTC was $0.61 \times 10^{6} \mathrm{ml}^{-1}$. Therefore, the gross growth rate of active bacteria can be divided into the rate of production of new inactive cells, $0.88 \mathrm{~d}^{-1}\left[\mu_{(\mathrm{i})}\right]$, and the rate of production of new active cells, $1.21 \mathrm{~d}^{-1}\left[\mu_{(\mathrm{a})}\right]$.

Estimaticn of grazing rates on active cells - The results from treatment D2, can be used to explore the dynamics of the bacterial populations in the presence of grazing by combining the data from all the other treatments. Because ambient substrate levels and temperature were similar in all the bags, we assume that the gross rate of production of new active cells $\left[\mu_{(\mathrm{a})}\right]$ was roughly the same in all treatments and similar to that calculated for the ungrazed samples $\left(1.21 \mathrm{~d}^{-1}\right.$, from above) and that the net rate of increase in the number of active bacteria, $r_{(\text {a) }}$, in each bag was the balance between $\mu_{(a)}$ and the grazing rates on active cells, $g_{(\mathrm{a})}$ :

$$
r_{(\mathrm{a})}=\mu_{(\mathrm{a})}-g_{(\mathrm{a})} .
$$

Because $\mu_{(\mathrm{a})}$ is assumed to be constant and $r_{(\mathrm{a})}$ can be calculated for each bag from the initial and final numbers of active cells, an estimate of $g_{\text {(a) }}$ can be derived from the data. The estimates of $g_{(\text {a) }}$ appear in Fig. 5A and were $\sim 2$-fold higher than the estimates of total loss rates $\left[g_{(\mathrm{t})}\right]$ calculated from the disappearance of minicells (Table 2). These independent estimates of grazing rates on active bacteria, however, were also strongly correlated to the initial density of HNF in the bags (Fig. 5B), suggesting 
that HNF were responsible not only for most of the overall bacterial losses $\left[g_{(\mathfrak{t})}\right]$ but also for the removal of active cells $\left[g_{(\mathbf{a})}\right]$.

Grazing on inactive cells - We can reconstruct the complete evolution of the bacterial populations in each bag by further assuming that the rate of cell inactivation $\left[\mu_{(i)}\right.$, from $\mathrm{D} 2$ above] was also constant in the different bags regardless of the amount of grazing by HNF. The net rate of increase in the number of inactive bacteria, $r_{(i)}$, is then the balance between the rate of production of new inactive cells, $\mu_{(\mathrm{i})}$ and the grazing rate on inactive cells, $g_{(\mathrm{i})}$ :

$$
r_{(\mathrm{i})}=\mu_{(\mathrm{i})}-g_{(\mathrm{i})}
$$

so that the final number of inactive cells is

$$
\begin{aligned}
\operatorname{INACT}_{(3)}= & \left\{\mathrm{ACT}_{(0)} \exp t\left[\mu_{(\mathrm{i})}-g_{(\mathrm{i})}\right]\right\} \\
& +\left\{\mathrm{INACT}_{(0)} \exp t\left[-g_{(\mathrm{i})}\right]\right\} .
\end{aligned}
$$

The second term of this equation refers to the initial pool of inactive cells, which decreased by $-g_{(\mathrm{i})}$ by $t=3 \mathrm{~d}$. It is now possible to express the final total bacterial abundance in each bag [ $\mathrm{TOT}_{(3)}$ ], in the presence of grazing, as a function of the increases in active and inactive cells:

$$
\begin{aligned}
\operatorname{TOT}_{(3)}= & \left\{\mathrm{ACT}_{(0)} \exp t\left[\mu_{(\mathrm{a})}-g_{(\mathrm{a})}\right]\right\} \\
& +\left\{\mathrm{ACT}_{(0)} \exp t\left[\mu_{(\mathrm{i})}-g_{(\mathrm{i})}\right]\right\} \\
& +\left\{\mathrm{INACT}_{(0)} \exp t\left[-g_{(\mathrm{i})}\right]\right\} .
\end{aligned}
$$

The only unknown variable in this equation is $g_{(i)}$, the grazing rate on inactive cells. Approximate values of $g_{(i)}$ can be obtained by simulating population growth by applying Eq. 1 to the actual initial and final TOT, ACT, and INACT values measured in the experiments, using the rates $\mu_{(\mathrm{a})}, g_{(\mathrm{a})}$, and $\mu_{(\mathrm{i})}$ calculated above, while varying $g_{(i)}$ to fit the observed data. There are two conditions in particular that the simulations had to satisfy: values close to both the measured final abundance of bacteria and the final proportion of active cells had to be achieved from the measured initial values. Grazing rates on inactive bacteria, $g_{(\mathrm{i})}$, were varied as a function of the known grazing rates on active cells, $g_{(\mathrm{a})}$, from $g_{(\mathrm{i})}=0$ to $g_{(\mathrm{i})}=2 g_{(\mathrm{a})}$.

Figure 6 shows the results of this simulation. When $g_{(\mathrm{i})}$ is assumed to equal or exceed $g_{(\mathrm{a})}$, both the resulting final bacterial abundance and proportion of active cells are widely divergent from our experimental results. Only values of $g_{(\mathrm{i})}$ that ranged from $g_{(\mathrm{i})}=0$ to $g_{(\mathrm{i})}=0.25 g_{(\mathrm{a})}$ yielded final bacterial densities similar to those measured (Fig. $6 \mathrm{~A})$ and final ratios of active and inactive cells that were also in good agreement with the cmpirical data (Fig. 6B). Although the exact magnitude of the difference between $g_{(\text {i) }}$ and $g_{(\text {(a) }}$ is still uncertain, the only reasonable explanation for our experimental results is that grazing on active cells was at least four times greater than grazing on inactive cells, and probably higher than that.

In plankton communities, size-selective ingestion is probably the main factor determining the selective removal of certain types of bacteria (Jürgens and Güde 1994), and size-selective grazing has been used to explain the selective removal of dividing cells from estuarine bac-
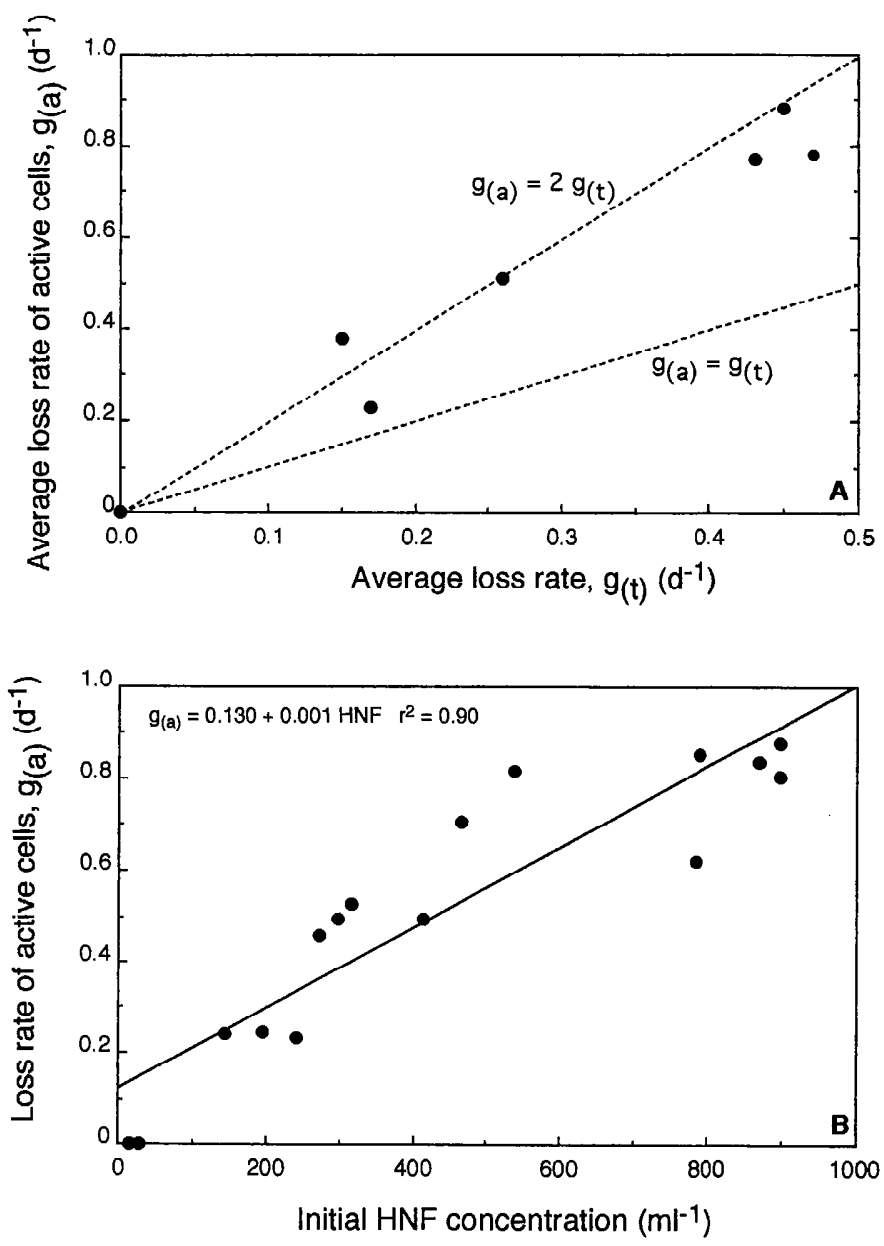

Fig. 5. A. The average estimated loss rates on active bacteria $\left[g_{(\mathrm{a})}\right]$ for each treatment as a function of the measured loss rates of bacteria $\left[g_{(t)}\right]$ in the same treatments. B. The estimated loss rates on active bacteria for the individual dialysis bags as a function of the initial density of HNF in the bags.

terioplankton (Sherr et al. 1992). The causes for the strong selective grazing on metabolically active cells in our experiments may also be traced to significant differences in cell size between active and inactive cells. Active cells, both in the ambient water and in the bags at the end of the experiments, were on average 2.2 times greater in volume than inactive cells (Gasol et al. 1995). The average volume of the minicells $\left(0.065 \mu \mathrm{m}^{3}\right)$ used for the grazing experiments coincided well with the average volume of the natural bacterioplankton of the Bay of Blanes $\left(0.06 \mu \mathrm{m}^{3}\right)$, so from this point of view, grazing on minicells may have been representative of grazing on the natural community. However, we did not directly measure loss rates of active and inactive cells, so we can only speculate on how loss rates measured by the disappearance of minicells (or similar methods) might relate to the actual loss rates experienced by active and inactive cells in natural populations.

In Fig. 5A we show that estimated loss rates of active cells are about double the loss rates measured for the 

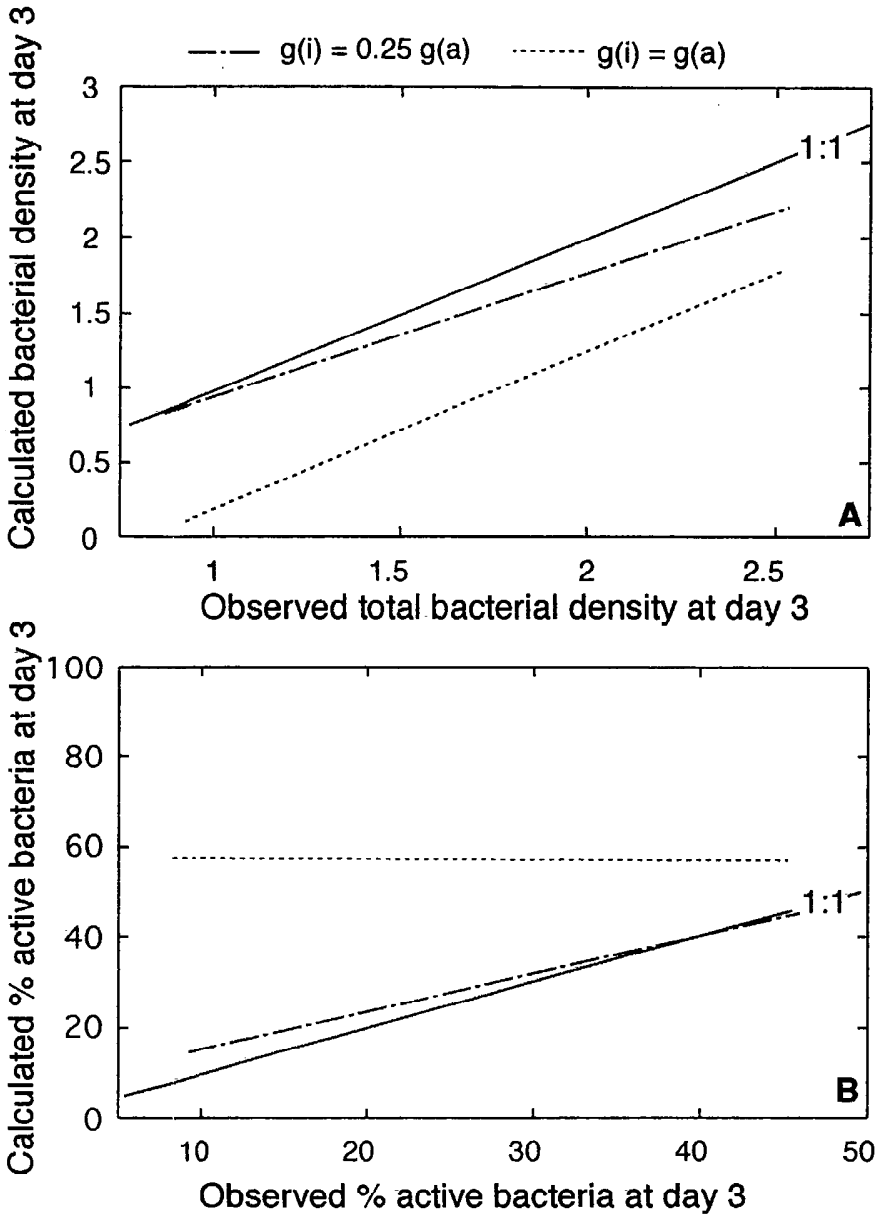

Fig. 6. Result of simulations to estimate the magnitude of grazing on inactive cells. Equation 1 (in text) was used together with the estimated $\mu_{(\mathrm{a})}, \mu_{(\mathrm{i})}, g_{(\mathrm{t})}$, and $g_{(\mathrm{a})}$, and grazing rates on inactive cells $\left[g_{(\mathrm{i})}\right]$ were varied from $g_{(\mathrm{i})}=0$ to $g_{(\mathrm{i})}=2 g_{(\mathrm{a})}$. A. Calculated total bacterial density at day 3 from the above simulation as a function of the observed total density. B. Calculated percent active cells at day 3 from the simulation as a function of the observed percent active cells. Only the line of equality and two simulations $\left[g_{(\mathrm{i})}=g_{(\mathrm{a})}\right.$, and $\left.g_{(\mathrm{i})}=2 g_{(\mathrm{a})}\right]$ are shown in both panels.

entire bacterial population. Interestingly, the measured bacterial loss rates $\left[g_{(\mathfrak{t})}\right.$, Table 2] are intermediate between the estimates of $g_{(\mathrm{i})}$ and $g_{(\mathrm{a})}$, suggesting that measures such as the disappearance of minicells provide estimates of grazing that tend to average or smooth the selective processes that occur within microbial communities. What is clear is that loss rates measured for the entire population cannot be directly extrapolated to active cells, and vice versa, but there does seem to be a relatively constant relation between the two (Fig. 5A). Moreover, the estimated loss rates of active bacteria increased linearly with initial HNF abundance (and with a log-slope not significantly different from 1, Fig. 5B), suggesting that the degree of selectivity by HNF remained approximately constant even when the total number of bacteria and the proportion of active cells varied among treatments. If grazing was indeed size-selective, the disappearance of minicells would tend to underestimate the removal of larger active cells (mean volume of $0.12 \mu \mathrm{m}^{3}$ ) and overestimate the removal of smaller inactive cells (mean volume of $0.055 \mu \mathrm{m}^{3}$ ). Size-selective grazing of active cells would tend to remove a disproportionately larger fraction of biomass and production than is currently estimated in grazing experiments that assume nonselective removal. The bias against larger active cells may explain why field measurements of grazing rates, scaled to the entire population, often fail to balance rates bacterioplankton growth (Pace 1988).

Present approaches in aquatic microbiology often treat the bacterial community as a "black box," where population processes such as growth, production, and loss are scaled-down to the entire bacterial density with the assumption that these processes are homogeneous within the bacterial community. We contend that our depiction of bacterial population dynamics (i.e. Eq. 1), which differentiates between active and inactive bacteria, provides a better frarnework for understanding these processes. In Fig. 7, we contrast the black-box approach (left panel) with an attempt to open up this box (right panel) by considering the initial pools of active and inactive cells, cell inactivation, and differential rates of grazing on both pools with data derived from our experiments. The net results of both the black-box approach and ours (Fig. 7) are similar, for example, in terms of final total bacterial density, and probably also in terms the total carbon respired, although gross bacterial production may be somewhat underestimated by models that assume nonselective processes. The pathways that led to the final numbers, however, are strikingly different in the two approaches, and the functional model they suggest is quite different too.

The causes of cell inactivation during our experiments are unclear. Various factors may induce cell inactivation, including temperature stress (Mason et al. 1986), starvation (Morita 1982), viral infection (Proctor and Fuhrman 1990), and ingestion by grazers followed by incomplete digestion (Gonzalez et al. 1990). Inactivation has also been hypothesized as a refuge mechanism against predation (Jürgens and Güde 1994), as supported by our results, which show the probability of surviving greatly increased if the cells were metabolically inactive. In the absence of environmental stresses that could induce cell inactivation, the process could still represent a mechanism to ensure the genetic and metabolic diversity of bacterial communities, which are in general heavily grazed (Sherr et al. 1992). What we call the inactive compartment is, however, a mixture of bacteria in various physiological states, including slow-growing cells, dormant or resting bacteria, and also dead bacteria, and the proportions of these different types is unknown.

These two main conclusions, grazer-control of the proportion of active cells and the occurrence of significant rates of cell inactivation, hinge on several assumptions. First, we have assumed in all our calculations that cells grew and divided from the pool of metabolically active cells and that metabolically inactive cells did not participate in growth at all. We consider the first assumption 
Homogeneous population non-selective processes

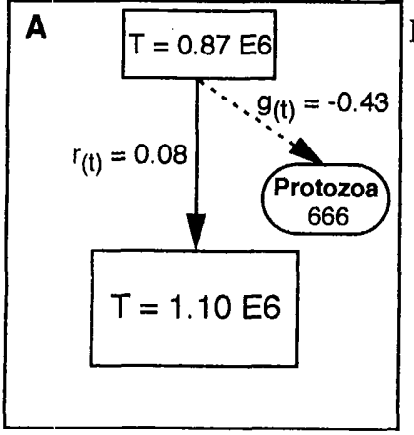

Heterogeneous population, selective processes

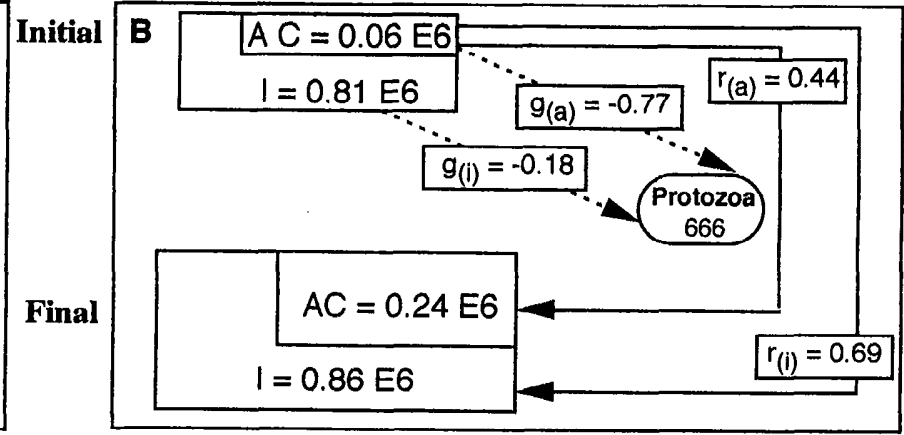

Fig. 7. Two alternative depictions of bacterioplankton dynamics in the dialysis bags. A. Bacterial growth in one of the treatments (Exp. A1), assuming that the bacterial population is homogeneous and that all cells participate in growth and are equally grazed by HNF. Calculations are based on the observed changes in total bacterial abundance $\left[r_{(t)}, d^{-1}\right]$ and on the measured grazing rates estimated from the disappearance of minicells $\left[g_{(t)}, d^{-1}\right]$ after $3 \mathrm{~d}$. B. Bacterial growth in the same treatment, assuming that the bacterial population is heterogeneous, that inactive cells do not participate in growth, and that active cells are selectively removed by HNF. Calculations are based on the observed changes in the number of active $\left[r_{(\mathrm{a})}, \mathrm{d}^{-1}\right]$ and inactive $\left[r_{(\mathrm{i})}, \mathrm{d}^{-1}\right]$ cells and on the estimated rates of grazing on active $\left[g_{(\mathrm{a})}, \mathrm{d}^{-1}\right]$ and inactive cells $\left[g_{(\mathrm{i})}, \mathrm{d}^{-1}\right]$. Solid lines represent growth $\left[r_{(x)}\right]$; broken lines represent grazing losses $\left[g_{(x)}\right]$. T is the total number of bacteria, $\mathrm{AC}$ the number of active cells, and $\mathrm{I}$ the number of inactive cells, all in $10^{6} \mathrm{ml}{ }^{-1}$ cells; density of protozoans is per milliliter.

safe, and other investigators have taken similar approaches (Riemann et al. 1984; Douglas et al. 1987). The second assumption may be more difficult to support, because in the same way that bacteria inactivate in natural communities (Morita 1982), they may also resume growth (Mason et al. 1986), and the circumstances under which this process occurs are not completely clear.

The third and perhaps most crucial assumption is that CTC is effective in discriminating active from inactive bacteria. Tetrazolium salts such as INT have been extensively used to detect respiring organisms, and one of the main limitations of the technique has been the difficulty of visualizing the intracellular deposits of formazan (Mason et al. 1986). Because CTC is reduced to a fluorescent formazan, the detection of cells with formazan deposits is greatly improved (Rodriguez et al. 1992), and our results suggest that CTC is sensitive to changes in the number of active cells. The extremely low initial densities of active cells in our experiments as determined by CTC, could be questioned, although similarly low proportions of active cells have been reported for the Mediterranean coast (Dufour and Colon 1992). These low initial proportions of active cells, however, were not an artifact of the method, because the same technique yielded up to $61 \%$ of active cells after $3 \mathrm{~d}$ of incubation without sample enrichment and at an intermediate temperature of $14^{\circ} \mathrm{C}$. The same CTC technique used here regularly yields proportions of active cells between 15 and $60 \%$ in lake bacterioplankton (del Giorgio and Scarborough 1995) and close to $100 \%$ in cultures of marine isolates (Choi et al. 1996), so low $(<10 \%)$ proportions of active cells are not inherent to this method. The proportions of active cells in some of the treatments at the end of the experiments were among the highest reported for natural marine bacterioplankton, including estimates from a variety of methods (Mason et al. 1986). An analysis of the size distribution of CTC + cells revealed that even the smallest cells $(<0.3-\mu \mathrm{m}$ diam) with fluorescent formazan deposits could be detected (Gasol et al. 1996). Overall, CTC seems to be a robust and sensitive method for estimating the number of respiring cells in natural bacterioplankton.

The results shown here suggest a 2-fold control of active bacteria subpopulations: first, selective grazing on active bacteria can remove new bacteria as they are being produced; second, cell inactivation may further remove cells from the active pool, probably more important when the number of active cells approaches or exceeds the carrying capacity of the system. The gross rate of production of active cells $\left(1.21 \mathrm{~d}^{-1}\right)$ was higher than the gross rate of cell inactivation $\left(0.88 \mathrm{~d}^{-1}\right)$, so in the absence of grazing, active cells would accumulate in the community but would tend to stabilize at $\sim 70-75 \%$ of the total number of bacteria. Cell inactivation may explain why percentages of active cells higher than $70-80 \%$ have seldom been reported for natural bacterioplankton communities (del Giorgio and Scarborough 1995; van Es and Meyer-Reil 1982). But because protist grazers seem to have such a strong preference for metabolically active cells, these are unlikely to build-up in natural populations, even in highly productive systems where resources are not limiting for bacteria, unless the density of protists is itself strongly constrained.

In lakes, for example, the highest bacterial densities together with the largest mean cell sizes occur in anoxic 
hypolimnia, regardless of the trophic status of the lakes (Cole et al. 1993). This pattern suggests that in anoxic waters bacteria are released from protozoan grazing and that in lakes, as in coastal marine waters, there is a strong size-selective grazing pressure on larger active bacteria, which results both in a low proportion of active cells and a low mean cell size in most surface waters. It could be further hypothesized that the proportion of active bacteria in anoxic hypolimnia should be higher than in overlying water. Thus, the differences in the proportion of active cells that have been reported among aquatic systems (del Giorgio and Scarborough 1995; Dufour and Colon 1992; Kogure et al. 1987) may be linked to systematic variations among these systems in the strength of trophic interactions within microbial communities, rather than to environmental constraints on bacterial growth, such as substrate or nutrient limitation.

Grazers, particularly HNF, seem to control the total number of bacteria and the proportion of active cells through postproduction grazing in a manner similar to that suggested by Sherr et al. (1992) for dividing cells. Ambient concentrations of HNF in these experiments were not unusually high, and the resulting loss rates were also well within the range measured for other marine and freshwater systems (Vaqué et al. 1994b). It is hypothesized that the low proportion of active bacteria found in many plankton communities may be the direct result of high grazing pressure on active cells rather than nutrient or substrate limitation. Dormant, dead, or extremely slowgrowing bacteria are thus able to persist in the community, and there must be a constant passage of cells from the active to the inactive pool and vice versa. These results further suggest that total bacterial density is not necessarily a reflection of the carrying capacity of aquatic systems but rather the combined result of growth, cell inactivation, and selective grazing.

\section{References}

BiRD, D. F., AND J. KALFF. 1993. Protozoan grazing and sizeactivity structure in limnetic bacterial communities. Can. J. Fish. Aquat. Sci. 50: 370-380.

CHOI, J. W., E. B. SHERR, AND B. F. SHerr. 1996. Relation between persence-absence of a visible nucleoid and metabolic activity in bacteroplankton cells. Limnol. Oceanogr. 41: 1161-1168.

Cole, J. J., and N. F. Caraco. 1993. The pelagic food web of oligotrophic lakes, p. 101-111. In T. E. Ford [ed.], Aquatic microbiology. Blackwell.

, M. L. Pace, N. F. Caraco, and G. S. Seinhart. 1993. Bacterial biomass and cells size distributions in lakes: More and larger cells in anoxic waters. Limnol. Occanogr. 38: $1627-1632$.

DEL GIORGIO, P. A., AND J. M. GASOL. 1995. Biomass distribution in freshwater plankton communities. Am. Nat. 146: 135-152.

, AND G. SCARBOROUGH. 1995. Increase in the proportion of metabolically active bacteria along gradients of enrichment in freshwater and marine plankton: Implications on estimates of bacterial growth and production rates. J. Plankton Res. 17: 1905-1924.
Douglas, D. J., J. A. Novitsky, AND R. O. FouRNIER. 1987. Microautoradiography-based enumeration of bacteria with estimates of thymidine-specific growth and production rates. Mar. Ecol. Prog. Ser. 36: 91-99.

DUfour, P., AND M. Colon. 1992. The tetrazolium reduction method for assessing the viability of individual bacterial cells in aquatic environments: Improvements, performance and applications. Hydrobiologia 232: 211-218.

DuckLOW, H. W., AND C. A. CARLSON. 1992. Oceanic bacterial production. Adv. Microb. Ecol. 12: 113-181.

, AND S. M. HILL. 1985. The growth of heterotrophic bacteria in the surface waters of warm core rings. Limnol. Oceanogr. 30: 239-259.

Gasol, J. M., P. A. Del Giorgio, R. Massana, and C. M. DUARTE. 1995. Active vs. inactive bacteria: Size-dependence in a coastal marine plankton community. Mar Ecol. Prog. Ser. 128: 91-97.

GonZALEZ, J. M., J. IriberRi, L. EgEA, AND I. Barcina. 1990. Differential rates of digestion of bacteria by freshwater and marine fagotrophic protozoa. Appl. Environ. Microbiol. 56: 1851-1857.

JÜRGENS, K., AND H. GÜDE. 1994. The potential importance of grazing-resistant bacteria in planktonic systems. Mar. Ecol. Prog. Ser. 112: 169-188.

Kogure, K., U. Simidu, N. TaGa, ANd R. R. Colwell. 1987. Correlation of direct viable counts with heterotrophic activity fo: marine bacteria. Appl. Environ. Microbiol. 53: 2332-2337.

Mason, C. A., G. HAMER, AND J. D. Bryers. 1986. The death and lysis of microorganisms in environmental processes. FEMS (Fied. Eur. Microbiol. Soc.) Microbiol. Rev. 39: 373401.

MoRITA, R. Y. 1982. Starvation-survival of heterotrophs in the marine environment. Adv. Microb. Ecol. 6: 171-197.

Mura, P., S. Agusti, P. A. Del Giorgio, J. M. Gasol, and C. M. DUARTE. 1996. Grazer-controlled production of nutrient-pcor littoral NW Mediterranean phytoplankton: In situ experimental evidence. Mar. Ecol. Prog. Ser. 130: 213219.

PACE, M. L. 1988. Bacterial mortality and the fate of bacterial production. Hydrobiologia 159: 41-49.

, G. B. MCManUS, AND S. E. G. Findlay. 1990. Planktonic community structure determines the fate of bacterial production in a temperate lake. Limnol. Oceanogr. 35: 795808.

Proctor, L. M., AND J. A. Fuhrman. 1990. Viral mortality of marine cyanobacteria and bacteria. Nature 343: 60-62.

RiemanN, B., P. Nielsen, M. Jeppersen, B. MARCusSen, AND J. A. FUHF:MAN. 1984. Diel changes in bacterial biomass and specific growth rates in coastal environments, determined by means of thymidine incorporation into DNA, frequency of dividing cells (FDC), and microautoradiography. Mar. Ecol. Prog. Ser. 17: 227-235.

RodrigueZ, G. G., D. PHipPS, K. IshigURo, AND H. F. Ridgeway. 1992. Use of a fluorescent redox probe for direct visualization of actively respiring bacteria. Appl. Environ. Microbiol. 58: 1801-1808.

Salat, J., A AND C. Marrasé. 1994. Exponential and linear estimations of grazing of bacteria: Effect on changes in the proportion of marked cells. Mar. Ecol. Prog. Scr. 104: 205209.

SANDers, R. W., D. A. CARon, ANd U.-G. Berninger. 1992. Relationships between bacteria and heterotrophic nanoplankton in marine and fresh waters: An inter-ecosystem comparison. Mar. Ecol. Progr. Ser. 86: 1-14. 
Schaule, G., H.-C. Flemming, and H. F. Ridgeway. 1993. Use of 5-cyano-2,3-ditolyl tetrazolium chloride for quantifying planktonic and sessile respiring bacteria in drinking water. Appl. Environ. Microbiol. 59: 3850-3857.

SHerr, B. F., E. B. SHerR, AND J. MCDANIEL. 1992. Effect of protistan grazing on the frequency of dividing cells in bacterioplankton assemblages. Appl. Environ. Microbiol. 58: 2381-2385.

Sherr, E. B., AND B. F. SherR. 1994. Bacterivory and herbivory: Key roles of phagotrophic protists in pelagic food webs. Microb. Ecol. 28: 223-235.

Stevenson, L. H. 1979. A case for bacterial dormancy in aquatic systems. Microb. Ecol. 4: 127-133.

Vaqué, D., S. Agustí, C. M. Duarte, S. Enriquez, and O. GEERTZ-HANSEN. 1994a. Microbial heterotrophs within
Codium bursa: A naturally isolated microbial food web. Mar. Ecol. Prog. Ser. 109: 275-282.

J. M. Gasol, AND C. Marrasé. 1994b. Grazing rates on bacteria: The significance of methodology and ecological factors. Mar. Ecol. Prog. Ser. 109: 263-274.

VAN ES, F. B., AND L.-A. MEYER-ReIL. 1982. Biomass and the metabolic activity of heterotrophic marine bacteria. Adv. Microb. Ecol. 6: 111-170.

WRIGHT, R. T. 1988. A model for short-term control of the bacterioplankton by substrate and grazing. Hydrobiologia 159: $111-117$.

Submitted: 12 April 1995 Accepted: 14 December 1995 Amended: 23 February 1996 